\title{
Patent Status Review and Ultra High Voltage Patent Analysis
}

\author{
Yuan Jiang ${ }^{1}$,Ziang $\mathrm{Hu}^{2}$,Likai Liang ${ }^{3}$, Tong Qiang ${ }^{4 *}$,Yiming Sun ${ }^{5}$ \\ School of Mechanical, Electrical\&Information Engineering Shandong University, Weihai,China \\ General Affairs Management Office,Shandong University, Weihai,China \\ 809672965@qq.com,243980481@qq.com, lianglikai@sdu.edu.cn, tronq@sdu.edu.cn,Sunyiming2018@163.com
}

\begin{abstract}
With more attention paid to the development of technology as well as the improvement of the public's knowledge level, there is an increasing trend in the application for the patents. However, the concerning documents for the development of the patents in our country are so limited, so carrying out a detailed research in this field is so necessary and urgent. Based on the statistics given by the SIPO, the growth rate of the patents' quantity and variation trend at home and abroad from 1986 to 2015 are analyzed and compared. Meanwhile, the patents quantity variation, the techno sphere constitution, the applicant and the the institution of a specialized field about ultra-high voltage transmission technology are studied. With the help of these authentic statistics, it is revealed that the development trend in our country is similar to that of the world level. But it is necessary to point out that there are some differences in the statistics during some fixed time periods. This research aims to offer some help for the progress of the patents' undertakings in our country and there is a sense in doing so.
\end{abstract}

Keywords-Patents;Patent analysis;Intellectual Property;UHV Transmission

\section{INTRODUCTION}

With the level of science constantly improving, the ability of innovation in science and technology are also constantly improved ${ }^{[1]}$. Nowadays, the core competitiveness of a country is increasingly manifested as its ability to cultivate, allocate and regulate intellectual resources and intellectual achievements ${ }^{[2]}$. For behindhand technological countries, the meaning of the independent innovation of science and technology is to rely on the creation ,protection and utilization of the patent, breaking through the bottlenecks of patent property rights. Then it will develop the growth of the national strength and the transformation of economic development patterns, forming new situation of national competitiveness and advantages ${ }^{[3]}$. Only after a country' specific application process and was awarded as a patent in domestic or other market,independent research and development' $\mathrm{s}$ resultst, in turn, made after the law on the protection, can transferred into market power and national competitive advantage [4]. Therefore, patents can be an important indicator to measure a country's independent technological innovation ${ }^{[5]}$.

Based on China's intellectual property rights that the data query, after comparison of the patent application and authorization in China with that of the world, we found that the change trend is basically the same, although there are some data showed some differences, but it still explain the cause of intellectual property rights in China steadily move closer to international standards. After entering the 21 st century, China's patent development with the international pace, with the international patent development system, and it can be seen in the data of recent years: China has become the world's largest patent applicant.

\section{ANALYSIS OF PATENT DEVELOPMENT AT HOME AND ABROAD}

\section{A. Application amount}

From the perspective of the change trend of total patent volume, the number of patent applications in the world has increased year by year, and China's statistics have been recorded since 1985. Being 32888 in 1986, the world patent applications, of which the patent application number is 23091 in our country, then it began increasing year by year. Each year' change of patent applications trend all over the world and China is shown in Fig.1. As can be seen from the figure, the development trend of China's patent application is basically the same as that of the world, and the growth trend is basically the same from 1986 to 2000. After entering the 21st century, our country and the world's patent applications tend to be a massive growth. And the growth rate is becoming more and more rapid, at the same time, during the period of 2013 to 2014 ,it has a small drop, but begining to grow again in 2015 . the number of that in 2015 is more than in 2013. Comparison from the perspectives of growth (as shown in Fig.2), an application for a patent for our country and around the world every five years of growth, is China's growth rate is significantly higher than the growth rate in the beginning, in 1996 to 2000, five years' gap is widenend, and then after entering the 21 st century growth rate is flattening, gradually in the 21 st century in the same growth rate.

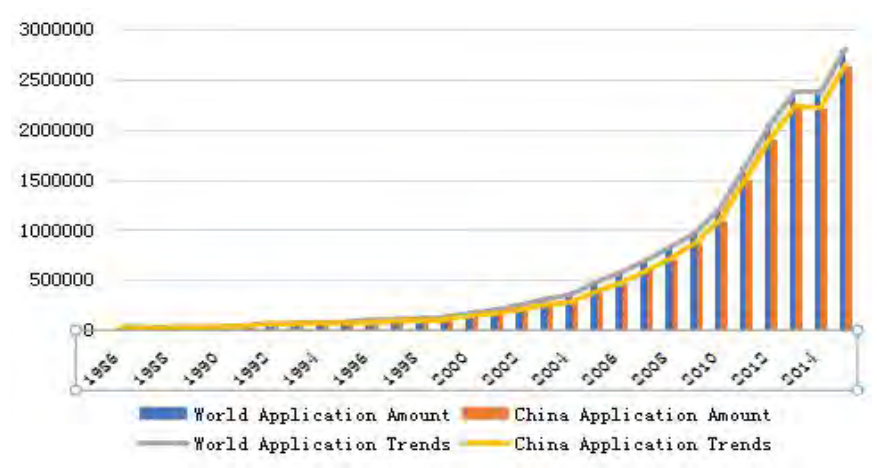

Fig. 1 Comparison of patent applications at home and abroad 


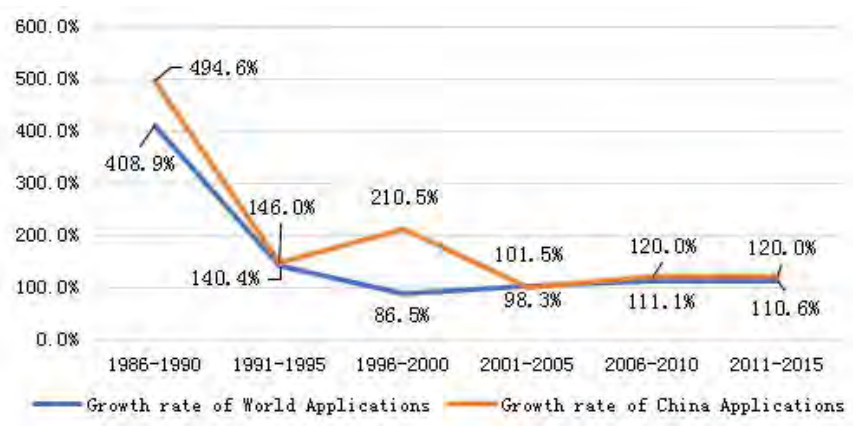

Fig. 2 Growth rate comparison of patent applications at home and abroad

\section{B. Authorization amount}

Since the beginning of the 21 st century, the number of patent applications granted worldwide has been increasing year by year. By 2015, it had reached 10446889, and in 2015 alone, 1718192. Patent grant from all around the world and the development trend of China's patent grant contrast (as shown in Fig.3) it can be seen clearly that in between 1986 and 2000, the world patent grant and the development trend in our country is basicly the same. After 2000, grant presented a rapid growth and it growed faster, but in 2012 it suddenly had a modest drop in the growth rate. Then continued in 2014, it can be seen clearly for a period of calm. Subsequently, in 2015, the number of patents granted worldwide and in China increased substantially, with 171,8192 patents granted in whole world and 159,6977 patents granted in China, both increasing by $32 \%$. It can be clearly seen from the comparison between the growth rate of patent granting in China and the world every five years (Fig.4) that the growth rate of patent granting both has maintained a similar growth rate.
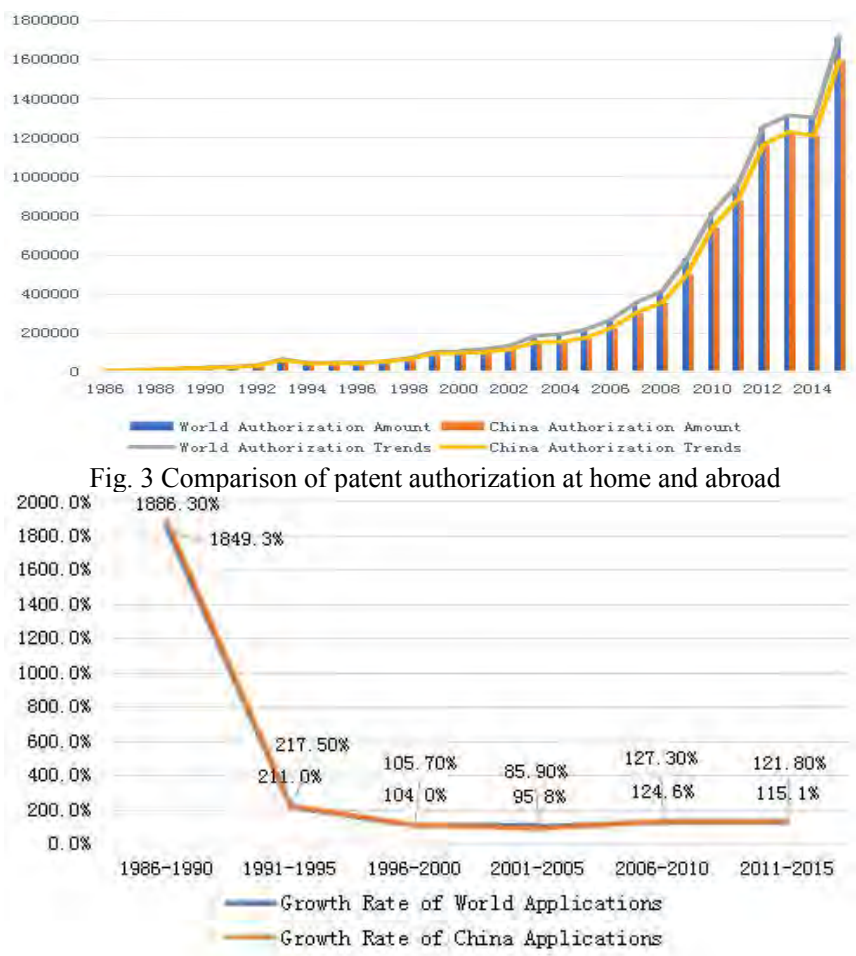

Fig. 4 Growth rate comparison of patent granting at home and abroad

\section{Development status of three types of patents}

According to the statistics, as of December 31, 2015, the number of patent applications worldwide was $182,53,281$, of which 6357,860 were invention patents, accounting for $34.8 \%$. The total number of patents for utility models was 662,5983 , accounting for $36.3 \%$. A total of 5269,438 design patents, accounting for $28.9 \%$ (Fig.5). By contrast, as of December 31, 2015, the number of patent applications in China was 16496810 , among which the number of invention patents was 4853594, accounting for $29.4 \%$. Utility model patents 6576708 , accounting for $39.9 \%$; The number of appearance design patents is 5066508 , accounting for $30.7 \%$ (Fig.6).

It is not hard to fins that, according to the statistics of the world, the proportion of appearance design accounts the least, while the proportion of invention and creation accounts the least when looking at the domestic data, but the proportion of utility model is the highest. This shows that the domestic invention in the creation of a slight deficiency in the class of utility models in the dominant position.

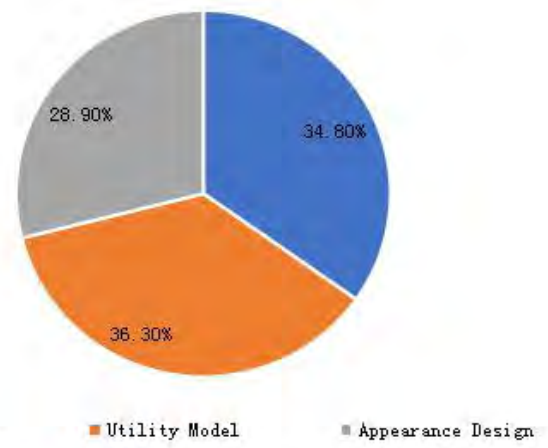

Fig.5 Proportion of world's three kinds of patent applications

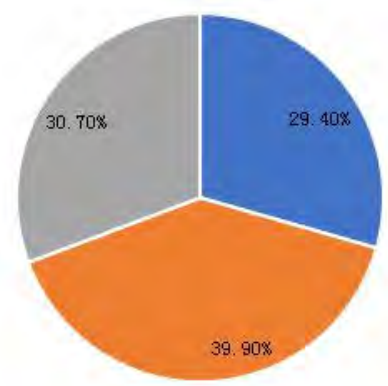

$=$ Invention $\quad=$ Utility Model $=$ Appearance Design

Fig.6 Proportion of China's three kinds of patent applications

Since the 21 st century, the number of patent applications has been increasing year by year all over the world. Specifically, the number of applications for invention patents also increased year by year. In 2015, the number of applications for invention patents was 1101,864 , accounting for $39.4 \%$ of the total. Utility models accounted for the fewest number of patents between 2004 and 2009, but the number of patents filed has increased every year since 2009. In 2015, the number of applications for utility model patents reached 112,7577 , accounting for $40.3 \%$ of the total number of applications in that year. From 2000 to 2012, the number of design patents increased year by year, but after 2012, the 
number of related patents began to decrease year by year. In 2015 , there were only 569,059 applications for design patents, accounting for $20.3 \%$ of the total number of patent applications (Fig.7).

By contrast, the number of invention patent applications in China has steadily increased year by year. From 25,356 in 2000 to 96,8251 in 2015 , an increase of $37.2 \%$. The number of applications for utility model patents in China has also been increasing steadily, especially after entering 2010, the number has been increasing explosively, and the growth rate is getting faster and faster. But the number of applications fell in 2014 , when 86,1053 utility model patents were filed, down to 2,4173 from 2013 , or 2.7 percent. But growth resumed in 2015 , when the number of patents filed was 11, 714. Overall, since the beginning of the 21 st century, the total number of applications has increased from 156,945 to 485,3594 in 2015 , an increase of 469,6649 , taking up about 29,92.5\% (Fig.8) 1200000

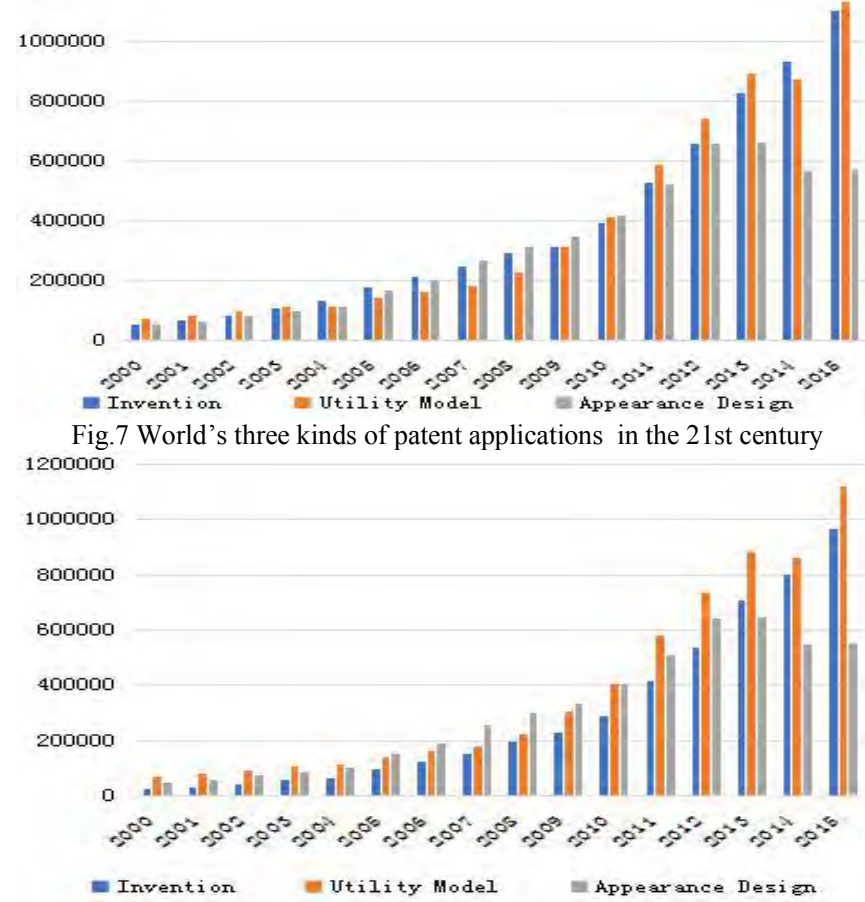

Fig. 8 China's three kinds of patent applications in the 21 st century

The following three figures are comparisons of the development trend of the world and China's three types of patent applications since the beginning of the 21st century. Figure 9 shows the the development trend of world and China's invention patent filings, it can be seen clearly that the development trend of a patent for invention is basically the same both in China and the world, applications are growing steadily year by year. Figure 10 illustrates all over the world and our country the trend of the development of the patent for utility model, can see clearly from the figure, two development trends of basic coincidence, is growing steadily, from 2013 to 2014 had only a small range of falling, but rising again in 2015. Figure 11 is the development trend of contrast, visible development trend is consistent, steadily rising first, after 2012 years into the flat, and a significant reduction in 2014 then development to flatten out.

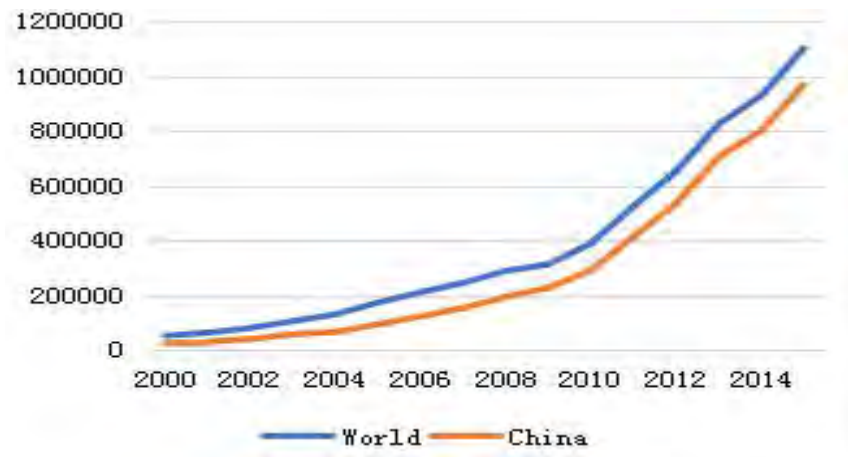

Fig. 9 Comparison of development trend of invention patent application

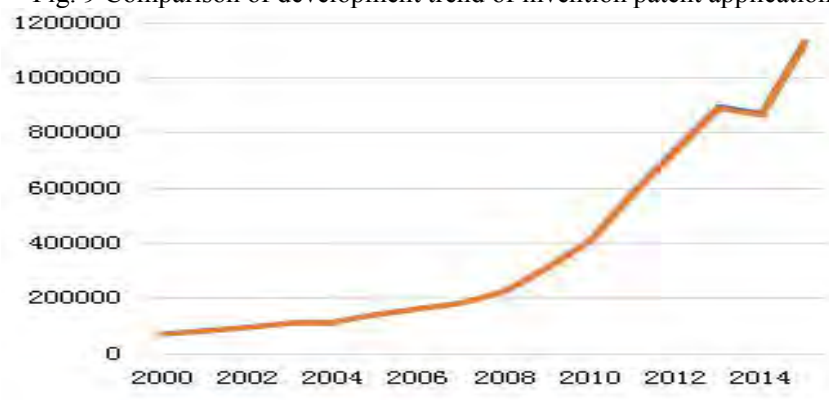

Fig.10 Comparison of development trend of utility model patent application 700000

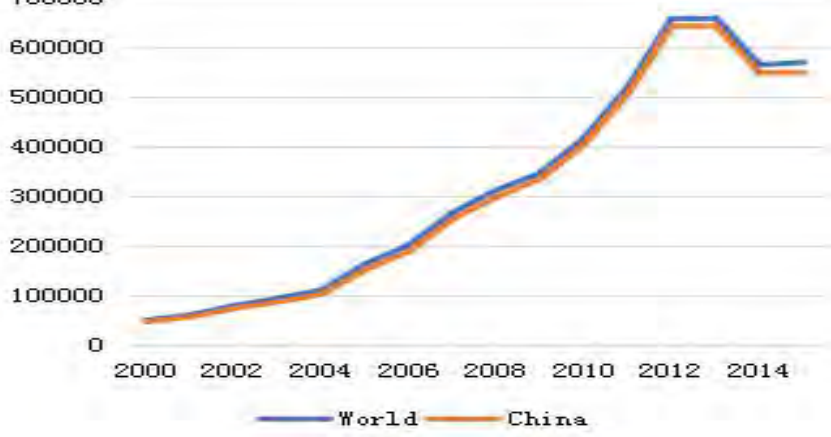

Fig.11 Comparison of development trend of patent application for appearance design

In general, China's existing patent business is developing well with great potential. After entering the 21 st century, it gradually moves towards international standards and connects with international standards. The development trend of patents is basically in line with the development trend of the world's patent industry. Both the number of applications for patents and the number of patents granted are basically the same as the development trend of the world.

\section{UHV TRANSMISSION IN CHINA}

With the constant improvement of the level of science and technology in our country and the higher and higher demand for electricity in east China, how to sending electricity to the nation, expand the electric power market, efficient use of energy become the focus in the study of power system. Studies found that UHV transmission technology with large transmission capacity, wide coverage, low dissipation, covers an area of less prominent advantages, can satisfy the interregional transmission of large capacity, long distance requirement ${ }^{[6]}$. Therefore, the planning and construction of uhv transmission network and the research and development 
of UHV transmission project will help to build a strong national power transmission network and promote the sustainable development of the energy industry. Uhv transmission can be divided into two different transmission modes, namely uhv ac transmission and UHV DC transmission ${ }^{[7]}$.Study of UHV power transmission first began in the late $1960 \mathrm{~s}$ by the former Soviet union, then the United States, Italy, Japan, Germany and other countries, according to the country's basic national conditions, formulate the plan of developing UHV power transmission project ${ }^{[8]}$.

Many UHV transmission projects in China have passed the examination and approved successively. Research in the field of its technology in our country, the construction of innovation in all get a lot of experience, applied for a large number of patents on UHV transmission, many research also become more deep, laid a solid foundation for long distance power transmission technology in our country. Therefore, during the period when the country vigorously developed UHV and a large number of related transmission projects were built in China, we made statistical analysis on the development of its science and technology related patents. Below we will start from the related patents statistics of UHV power transmission, making statistical analysis and discussion to the existing number of patent application of UHV transmission technology and the applicant organisation in China.

\section{A. Application amount}

As of March 20, 2017, a total of 454 patent applications for UHV transmission have been retrieved from the Chinese patent retrieval system. Among them, there are 232 applications for invention patents, accounting for 51.1\%, 219 patents for utility models, accounting for $48.2 \%$, and 3 designs for appearance, accounting for $0.6 \%$. The annual distribution of its application amount is shown in figure 12 . As can be seen from the figure, from 2008 to 2010, the number of patent applications increased year by year. After that, there was a significant decline in 2011, but after 2011, the number of patent applications related to UHV transmission increased again. However, there was a small decline in 2015, which rose again in 2016 and peaked at 80 pieces. It illustrates that as China's construction of the UHV transmission, a lot of research were established and we obtained many achievements of patent.

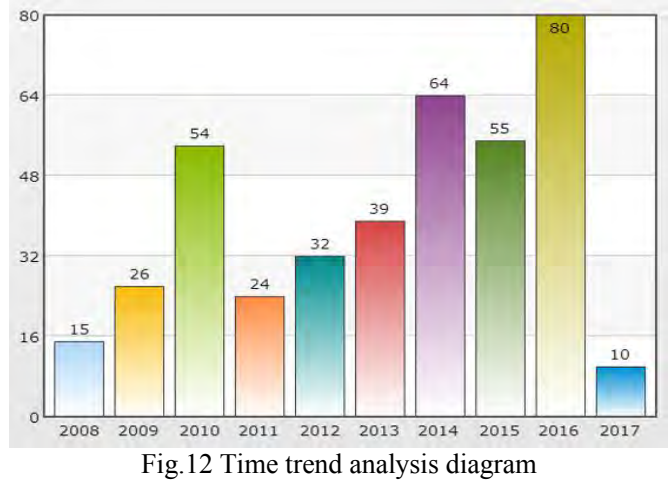

Fig.12 Time trend analysis diagram

\section{B. Key technology research and development}

Through the Chinese patent retrieval system, I searched and classified the patents related to uhv transmission technology, and classified them according to the international patent standards. In the process and results of the statistics found that the uhv transmission technology in our country related patent, patent research and development in our country focus mainly concentrated in the power generation, substation and power distribution of $\mathrm{H}$, and measuring, testing, calculation of $\mathrm{G}$, the specific distribution as shown in Fig.13.

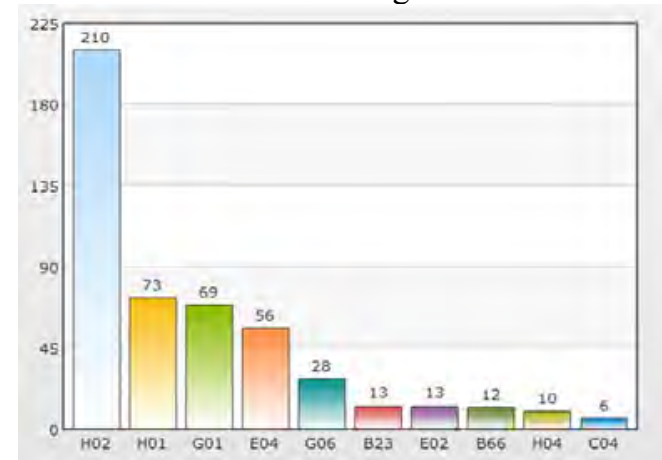

Fig.13 Analysis diagram of technical field composition

In China, the applicants for patents related to ultra-high voltage transmission are mainly concentrated in power grid companies, research and design institutes, etc. The patents filed by each of its applicants are mainly in the H01 (basic electrical components), E04 (buildings) and H02 (power generation, transmission or distribution) sections, the most are in the $\mathrm{H} 02$ section. In the part of $\mathrm{H} 02$, state grid corporation of China has the highest number of patent applications, indicating a high proportion, accounting for about $40 \%$ of the total. In the G01 section, only one company and two research and design institutes have applied for patents in this section.IPC subclass meaning notes are shown in Table 1.

TABLE I. IPC SUBCLASS COMMENTS

\begin{tabular}{|c|c|c|}
\hline No. & IPC & Notes \\
\hline 1 & $\mathrm{HO} 2$ & To convert or distribute electricity \\
\hline 2 & H01 & Basic electrical element \\
\hline 3 & G01 & Measurement test \\
\hline 4 & $\mathrm{E} 04$ & Building \\
\hline 5 & G06 & Calcul ating, counting \\
\hline 6 & B23 & Machine tool;-Metal processing not imcluded in other categories \\
\hline 7 & $\mathrm{E} 02$ & Water conservancy project;Basis;Dredging \\
\hline 8 & B66 & Hoisting traction \\
\hline 9 & HO4 & Telecommunication technology \\
\hline 10 & $\mathrm{CO4}$ & Cement;Concrete; Artificial stone;Ceramic;R efractory \\
\hline
\end{tabular}

In detail, the key to UHV transmission technology research and development of patent in China including power 
equipment, control, protection technology, electromagnetic environment and experimental simulation technology, related technology research and development focus on details are listed in Table 2.

The technical research and development of patents related to UHV transmission engineering in China mainly focus on two aspects. One is electrical equipment, including circuit materials, towers and circuit breakers. The other is protection control technology, including various measurement methods, stability control methods and other aspects. And these are the key technologies to solve the problems after construction and transportation. Secondly, electromagnetic environment control and simulation experiment simulation technology are two aspects of great concern to domestic research institutions, universities and experts and scholars in the industry.

TABLE II. IPC SUBCLASS COMMENTS

\begin{tabular}{|c|c|c|c|c|c|c|c|c|}
\hline $\begin{array}{c}\text { Electric } \\
\text { power } \\
\text { equipment }\end{array}$ & $\begin{array}{l}\text { Amo } \\
\text { unt }\end{array}$ & $\begin{array}{c}\text { Proporti } \\
\text { on }\end{array}$ & $\begin{array}{l}\text { Control and } \\
\text { protection } \\
\text { technology }\end{array}$ & $\begin{array}{c}\text { Amou } \\
\text { nt }\end{array}$ & $\begin{array}{c}\text { Propor } \\
\text { tion }\end{array}$ & $\begin{array}{c}\text { Electromagnetic } \\
\text { environment }\end{array}$ & $\begin{array}{c}\text { Amou } \\
\text { nt }\end{array}$ & $\begin{array}{l}\text { Propo } \\
\text { rtion }\end{array}$ \\
\hline $\begin{array}{l}\text { Transmissio } \\
n \text { conductor }\end{array}$ & 90 & $34.0 \%$ & \multirow{2}{*}{$\begin{array}{c}\text { Measurement } \\
\text { method of uhv } \\
\text { transmission } \\
\text { system }\end{array}$} & \multirow[t]{2}{*}{52} & \multirow[t]{2}{*}{$41.0 \%$} & \multirow{5}{*}{$\begin{array}{l}\text { Electromagnetic } \\
\text { environment } \\
\text { control for } \\
\text { ultra-high voltage } \\
\text { transmission }\end{array}$} & \multirow{5}{*}{27} & \multirow{5}{*}{$6 \%$} \\
\hline $\begin{array}{c}\text { Transmissio } \\
n \text { pole }\end{array}$ & 84 & $31.7 \%$ & & & & & & \\
\hline Insulator & 54 & $20.4 \%$ & \multirow{2}{*}{$\begin{array}{l}\text { Fault analysis, } \\
\text { testing, } \\
\text { troubleshooting }\end{array}$} & \multirow[t]{2}{*}{50} & \multirow[t]{2}{*}{$39.4 \%$} & & & \\
\hline $\begin{array}{l}\text { Surge } \\
\text { arrester }\end{array}$ & 11 & $4.2 \%$ & & & & & & \\
\hline \multirow{2}{*}{$\begin{array}{c}\text { Circuit } \\
\text { breaker, } \\
\text { isolation } \\
\text { switch }\end{array}$} & \multirow[t]{2}{*}{9} & \multirow[t]{2}{*}{$3.3 \%$} & \multirow{3}{*}{ 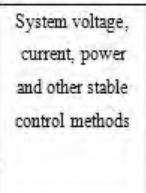 } & \multirow[t]{3}{*}{14} & \multirow[t]{3}{*}{$11.0 \%$} & & & \\
\hline & & & & & & $\begin{array}{l}\text { Experimental } \\
\text { simulation } \\
\text { technology }\end{array}$ & $\begin{array}{c}\text { Amou } \\
\text { nt }\end{array}$ & $\begin{array}{l}\text { Propo } \\
\text { rtion }\end{array}$ \\
\hline transformer & 8 & $3.0 \%$ & & & & \multirow{3}{*}{$\begin{array}{l}\text { Simulation } \\
\text { technology }\end{array}$} & \multirow{3}{*}{36} & \multirow{3}{*}{$8.0 \%$} \\
\hline reactor & 7 & $2.6 \%$ & Relay protection & 9 & $7.1 \%$ & & & \\
\hline \multicolumn{3}{|c|}{$\begin{array}{l}\text { In addition, it also involves } \\
\text { transformers, capacitors, GIS and } \\
\text { other aspects }\end{array}$} & \multicolumn{3}{|c|}{$\begin{array}{l}\text { In addition, overcurrent suppression, } \\
\text { converter suppression, voltage } \\
\text { suppression, system optmization } \\
\text { methods and other aspects are also } \\
\text { involved }\end{array}$} & & & \\
\hline
\end{tabular}

\section{CONCLUSION}

Statistically speaking, domestic and foreign patent applications will increase steadily year by year,.After entering the 21 st century, despite the poor performance of the global economy but patent applications around the world have developed steadily. In addition, the three types of patents at home and abroad also have their own development trends. In addition to the decline in the number of applications for appearance design in recent years, both invention patents and utility model patents are increasing year by year.

Although since the reform and opening up, China's patent applications have increased to a certain extent with the help of the state and the unremitting efforts of researchers. But it can be seen with other science and technology leading countries compared with developed areas, the development of science and technology level in our country is still in a relatively backward situation, leading to apply for patent on the quality and quantity of it, all is in a state of backwardness. Moreover, it can be concluded from the above analysis data that the patent applicants in China are still concentrated in two aspects: one is the research institute, the other is the university. However, many enterprises that should have come up with patents, especially processing enterprises, are still in the state of "zero patents". Because of this, most of these patents have not been commercialized or put into production as scientific research achievements and have not created the economic benefits that should be created. And some patents are really experimental, not productive. Therefore, most of these patents do not cooperate with enterprises, that is, cannot be converted into productivity, thus they have neither economic value nor social value ${ }^{[9]}$.

To sum up, great China, which is committed to the path of independent innovation, is bound to enter a new and more confident stage of independent innovation. From quantity expansion to quality improvement, from technical capability to technical capability diversification. The fundamental transformation of China's economic development pattern, the re-shaping of China's competitive advantage and the dream of the great rejuvenation of the Chinese nation will all be based on this solid foundation.If Chinese enterprises want to gain a competitive edge in the domestic high-end products market, valuable patent portfolio also must rely on to build competitors enter the fortress, constantly rely on patent to create exclusive product market and development space, it can be cracked foreign competitors' intellectual property rights restriction ${ }^{[10]}$.Therefore, it is necessary for all enterprises in China to raise their awareness of patent strategy and build our new Great Wall of patent.

\section{ACKNOWLEDGMENT}

This work was supported by the National Natural Science Foundation of China (61473174) and Weihai Science and Technology Project (2018).Corresponding author:Tong Qiang.

\section{REFERENCES}

[1] Yang zhongkai, patent measurement and patent system [M], dalian university of technology press, 2008, first edition.

[2] Alex fung, "hu said to strengthen the system construction of intellectual property rights in China provide strong support for our country into an innovative country" [J], "high-tech enterprises in China", 2006.

[3] $\mathrm{Yu}$ wenhua, new trends of independent innovation in China [M], Beijing intellectual property press, 2014, first edition.

[4] Liu renzhi, breakthrough zero patents - patent strategy in technological innovation, Beijing chemical industry press, 2015, first edition.

[5] Luan chunjuan, patent measurement and patent strategy, dalian university of technology press, 2012, first edition.

[6] Liu zhenya, "ultra-high voltage power grid", China economic press, 2005, first edition.

[7] Yang li, "ultra-high voltage transmission technology", China water and hydropower press, 2011, first edition.

[8] "1000kV ultra-high voltage ac transmission technology", electrical abstract, 6 (2008).

[9] Wang yu-min, strategies and applications of commercialization of patents, science press, 2007, first edition.

[10] Luan chunjuan, patent measurement and patent warA. Dalian university of technology press, 2012, first edition. 